\title{
Antimicrobial Stewardship Implementation in Nigerian Hospitals: Gaps and Challenges
}

\author{
${ }^{* 1}$ Iregbu, K. C., ${ }^{1}$ Nwajiobi-Princewill, P. I., ${ }^{1}$ Medugu, N., ${ }^{2}$ Umeokonkwo, C. D., \\ ${ }^{3}$ Uwaezuoke, N. S., ${ }^{4}$ Peter, Y. J., ${ }^{5}$ Nwafia, I. N., ${ }^{6}$ Elikwu, C., ${ }^{7}$ Shettima, S. A., \\ ${ }^{8}$ Suleiman, M. R., ${ }^{9}$ Awopeju, A. T. O., ${ }^{10}$ Udoh, U., ${ }^{11}$ Adedosu, N., ${ }^{12}$ Mohammed, A., \\ ${ }^{13}$ Oshun, P., ${ }^{14}$ Ekuma, A., ${ }^{15}$ Manga, M. M., ${ }^{16}$ Osaigbovo, I. I., ${ }^{17}$ Ejembi, C. J., \\ ${ }^{18}$ Akujobi, C. N., ${ }^{19}$ Samuel, S. O., ${ }^{20}$ Taiwo, S. S., and ${ }^{13}$ Oduyebo, O. O.
}

\begin{abstract}
${ }^{1}$ National Hospital Abuja, Nigeria; ${ }^{2}$ Alex Ekwueme Federal Teaching Hospital, Abakaliki; ${ }^{3}$ Federal Medical Centre, Jabi, Abuja, Nigeria; ${ }^{4}$ University of Abuja Teaching Hospital, Gwagwalada; ${ }^{5}$ University of Nigeria Teaching Hospital, Enugu; ${ }^{6}$ Babcock University Teaching Hospital, Ilishan-Remo, Nigeria; ${ }^{7}$ Federal Medical Centre, Yola; ${ }^{8}$ Federal Medical Centre, Katsina; ${ }^{9}$ University of Port Harcourt Teaching Hospital, Port Harcourt; ${ }^{10}$ University of Calabar Teaching Hospital, Calabar; ${ }^{11}$ Federal Medical Centre, Owo; ${ }^{12}$ Usmanu Danfodiyo University Teaching Hospital, Sokoto; ${ }^{13}$ Lagos University Teaching Hospital, Lagos; ${ }^{14}$ University of Uyo Teaching Hospital, Uyo; ${ }^{15}$ Federal Teaching Hospital, Gombe; ${ }^{16}$ University of Benin Teaching Hospital, Benin-City; ${ }^{17} \mathrm{Ahmadu}$ Bello University Teaching Hospital,

Zaria; ${ }^{18}$ Nnamdi Azikiwe University Teaching Hospital, Nnewi; ${ }^{19}$ Irrua Specialist Teaching Hospital, Irrua;

${ }^{20}$ Ladoke Akintola University of Technology Teaching Hospital, Ogbomoso, Nigeria.
\end{abstract}

*Correspondence to: keniregbu@yahoo.co.uk

\begin{abstract}
:
Background: Antimicrobial resistance (AMR) is a major clinical challenge globally. It is mainly a consequence of inappropriate prescribing and use of antibiotics. Antimicrobial stewardship (AMS) ensures that antibiotics are prescribed and used appropriately. This study assessed AMS practice in selected Nigerian hospitals.

Methodology: This was a cross sectional survey of 20 Federal, State and Private tertiary hospitals randomly selected from the six geopolitical zones of Nigeria. Using an adapted WHO tool on AMS, data were collected from each hospital as regard the existence of AMS committee, Accountability and Responsibility, AMS actions, Education and Training, Monitoring and Evaluation, Infection Prevention and Control (IPC) practice, facilities to support AMS, and challenges to AMS implementation. Gaps and challenges to the implementation of the AMS among the hospitals were identified. Results: Only $6(30 \%)$ of the 20 hospitals had AMS committees while $2(10 \%)$ had any evidence of leadership commitment to AMS. All the hospitals had laboratory facilities to support culture and sensitivity testing. There were no regular AMS-related education or training, monitoring, evaluation or reporting activities in the hospitals, except in $7(25 \%)$ that had participated in the global point prevalence survey (Global-PPS) of antimicrobial use and resistance being hosted by the University of Antwerp, Belgium. Challenges impeding AMS activities included lack of human and financial resources, prescribers' opposition, lack of awareness and absence of AMS committees. Most of the gaps and challenges bordered on seeming lack of knowledge and inadequate communication among prescribers and other stakeholders.

Conclusion: There is need for intense education and training activities for prescribers and other stakeholders, including but not limited to hospital administrators.
\end{abstract}

Keywords: Survey, Antimicrobial Stewardship, Antimicrobial Resistance; Nigeria

Received Sept 24, 2020; Revised Oct 10, 2020; Accepted Oct 24, 2020

Copyright 2021 AJCEM Open Access. This article is licensed and distributed under the terms of the Creative Commons Attrition 4.0 International License <a rel="license" href="http://creativecommons.org/licenses/by/4.0/", which permits unrestricted use, distribution and reproduction in any medium, provided credit is given to the original author(s) and the source. Editor-in-Chief: Prof. S. S. Taiwo

\section{Mise en œuvre de la gestion des antimicrobiens dans les hôpitaux Nigérians: lacunes et défis}

\author{
${ }^{* 1}$ Iregbu, K. C., ${ }^{1}$ Nwajiobi-Princewill, P. I., ${ }^{1}$ Medugu, N., ${ }^{2}$ Umeokonkwo, C. D., \\ ${ }^{3}$ Uwaezuoke, N. S., ${ }^{4}$ Peter, Y. J., ${ }^{5}$ Nwafia, I. N., ${ }^{6}$ Elikwu, C., ${ }^{7}$ Shettima, S. A.,
}


${ }^{8}$ Suleiman, M. R., ${ }^{9}$ Awopeju, A. T. O., ${ }^{10}$ Udoh, U., ${ }^{11}$ Adedosu, N., ${ }^{12}$ Mohammed, A., ${ }^{13}$ Oshun, P., ${ }^{14}$ Ekuma, A., ${ }^{15}$ Manga, M. M., ${ }^{16}$ Osaigbovo, I. I., ${ }^{17}$ Ejembi, C. J., ${ }^{18}$ Akujobi, C. N., ${ }^{19}$ Samuel, S. O., ${ }^{20}$ Taiwo, S. S., et ${ }^{13}$ Oduyebo, O. O.

*11Hôpital national d'Abuja, Nigéria; ${ }^{2}$ Hôpital universitaire fédéral Alex Ekwueme, Abakaliki;

${ }^{3}$ Centre médical fédéral, Jabi, Abuja, Nigéria; ${ }^{4} \mathrm{Hôpital} \mathrm{d'enseignement} \mathrm{de} \mathrm{I'Université} \mathrm{d'Abuja,} \mathrm{Gwagwalada;}{ }^{5} \mathrm{Hôpital}$ d'enseignement de I'Université du Nigéria, Enugu; ${ }^{6} \mathrm{Hôpital} \mathrm{universitaire} \mathrm{de} \mathrm{Babcock,} \mathrm{Ilishan-Remo,} \mathrm{Nigéria;}{ }^{7}$ Centre médical fédéral, Yola; ${ }^{8}$ Centre médical fédéral, Katsina; ${ }^{9} \mathrm{Hôpital}$ d'enseignement de I'Université de Port Harcourt,

Port Harcourt; ${ }^{10} \mathrm{Hôpital}$ d'enseignement de I'Université de Calabar, Calabar; ${ }^{11}$ Centre médical fédéral, Owo; ${ }^{12}$ Hôpital universitaire Usmanu Danfodiyo, Sokoto; ${ }^{13} \mathrm{Hôpital}$ universitaire de Lagos, Lagos; ${ }^{14}$ Université de I'hôpital d'enseignement d'Uyo, Uyo; ${ }^{15} \mathrm{Hôpital}$ universitaire fédéral de Gombe; ${ }^{16} \mathrm{Hôpital} \mathrm{d'enseignement} \mathrm{de} \mathrm{I'Université} \mathrm{du}$ Bénin, Benin-City; ${ }^{17}$ Hôpital universitaire d'Ahmadu Bello, Zaria; ${ }^{18}$ Hôpital universitaire Nnamdi Azikiwe, Nnewi;

${ }^{19} \mathrm{Hôpital}$ universitaire spécialisé d'Irrua, Irrua; ${ }^{20} \mathrm{Hôpital} \mathrm{d'enseignement} \mathrm{de} \mathrm{I'Université} \mathrm{de} \mathrm{technologie}$ Ladoke Akintola, Ogbomoso, Nigéria

*Correspondance à: keniregbu@yahoo.co.uk

\section{Abstrait:}

Contexte: La résistance aux antimicrobiens (RAM) est un défi clinique majeur à l'échelle mondiale. C'est principalement une conséquence d'une prescription et d'une utilisation inappropriées d'antibiotiques. La gestion des antimicrobiens (AMS) garantit que les antibiotiques sont prescrits et utilisés de manière appropriée. Cette étude a évalué la pratique de l'AMS dans certains hôpitaux Nigérians.

Méthodologie: Il s'agissait d'une enquête transversale de 20 hôpitaux tertiaires fédéraux, d'État et privés sélectionnés au hasard dans les six zones géopolitiques du Nigéria. À l'aide d'un outil OMS adapté sur l'AMS, des données ont été collectées auprès de chaque hôpital en ce qui concerne l'existence d'un comité AMS, la responsabilité et la responsabilité, les actions AMS, l'éducation et la formation, le suivi et l'évaluation, la pratique de prévention et de contrôle des infections (IPC), les installations pour soutenir l'AMS. et les défis de la mise en œuvre de I'AMS. Les lacunes et les défis liés à la mise en œuvre de l'AMS parmi les hôpitaux ont été identifiés.

Résultats: Seuls $6(30 \%)$ des 20 hôpitaux avaient des comités AMS tandis que $2(10 \%)$ avaient des preuves d'engagement du leadership envers I'AMS. Tous les hôpitaux disposaient d'installations de laboratoire pour soutenir la culture et les tests de sensibilité. Il n'y avait pas d'activités régulières d'éducation ou de formation, de suivi, d'évaluation ou de rapportage liées à la MGS dans les hôpitaux, sauf dans 7 (25\%) qui avaient participé à l'enquête mondiale sur la prévalence ponctuelle (Global-PPS) de l'utilisation et de la résistance aux antimicrobiens organisée par l'Université d'Anvers, Belgique. Les défis entravant les activités de l'AMS comprenaient le manque de ressources humaines et financières, l'opposition des prescripteurs, le manque de sensibilisation et l'absence de comités AMS. La plupart des lacunes et des défis se limitaient à un manque apparent de connaissances et à une communication inadéquate entre les prescripteurs et les autres intervenants.

Conclusion: Des activités d'éducation et de formation intensives sont nécessaires pour les prescripteurs et autres intervenants, y compris, mais sans s'y limiter, les administrateurs d'hôpitaux.

Mots clés: enquête, gestion des antimicrobiens, résistance aux antimicrobiens; Nigeria

\section{Introduction:}

Antimicrobial resistance (AMR) has become a major challenge in clinical practice especially in the management of bacterial infections. The discovery of penicillin by Fleming in 1928 revolutionized medicine and brought hope of eradicating infections as exemplified by the infamous quote allegedly made by the United States Surgeon General Dr. Willian H. Stewart about 1967-1969, for which no source has been traced till date $(1,2)$. Notwithstanding, the quote "it is time to close the books on infection and declare the war against pestilence won" was often used to underscore the everincreasing challenge of antibiotic-resistant and emerging infections.

The tendency of bacteria to develop resistance to antibiotics and its likely negative impact was revealed by Fleming in his Nobel prize award lecture in 1945 (3). Presently many common clinical isolates have developed one form of resistance or the other to most of the commonly used antibiotics and this has led to increased morbidity, mortality, length of hospital stay and healthcare cost. Between 1996 and 2018, the prevalence of methicillin resistance in Staphylococcus aureus rose from below $10 \%$ to above $50 \%$ in many countries in Africa, including Nigeria (5-8). It is estimated that at present, antibiotic resistance kills about 700,000 yearly worldwide, and that this figure has been projected to rise to about 10 million by 2050, with attendant economic crises (4).

Several studies have identified antibiotic selective pressure as the single most important driver of resistance in bacteria. The selective pressure results from use of antibiotics, particularly when used inappropriately $(9,10$,$) . In a$ study by Hecker et al., (11), it was reported that $576(30 \%)$ of a total of 1941 antimicrobial days of therapy prescribed for 129 patients were 
unnecessary. The most common reasons for the unnecessary therapy included longer therapy than recommended (33\%), non-infectious/nonbacterial syndrome $(32 \%)$, colonizing or contaminating organisms (16\%) and redundant prescriptions (10\%). Similarly, antibiotic use has been found to correlate with antibiotic resistance (12-15); the more antibiotics are used, the more resistance develops and vice-versa. The World Health Organisation (WHO) estimates that by 2050 , antimicrobial resistance will cost the world about $\$ 100$ trillion per annum if left unchecked (16). The WHO has also warned that the world is running out of antibiotics, and therefore urgent action is required for remedy (17).

To stem the emergence and rise in AMR and reserve drugs for the future, rational antibiotic use in humans and animal husbandry was recognized as a key strategy $(18,19)$. The antimicrobial stewardship (AMS) strategy was introduced to ensure that only the right patient is given the right antibiotics for the right indication in the right dose for the right duration using the right route with the goals of reducing emergence of resistance, morbidity, mortality, length of hospital stay and healthcare cost due to infectious diseases $(19,20)$. This strategy is in use in many parts of the world, especially in the developed countries. In Nigeria, the availability of antimicrobial stewardship programmes (ASPs) in hospitals is grossly inadequate and antimicrobial prescribing patterns are largely empirical (21).

This cross-sectional survey of Federal, State and Private tertiary hospitals in Nigeria was therefore designed to identify gaps and challenges that have stood against AMS practice in the country, the result of which is expected to serve as guide for stakeholders in planning for and implementing AMS programmes to improve the quality of healthcare and safety of patients.

\section{Materials and method:}

\section{Study setting}

The study setting is the Nigeria health system, which is structured in a tiered hierarchical manner; primary, secondary, and tertiary hospitals. These hospitals are under the controls of different administrative levels and provide varying complexity of services. The tertiary hospitals are the most specialized and are often under the control of the Federal (mostly) and some State Government, as well as few Private (Faith-based) organizations. They are often the most funded and have specialized manpower to provide tertiary level health care, training and research. They comprise the university teaching hospitals, federal medical centers, and specialized hospitals such as the neuropsychiatric and the orthopaedic hospitals. These hospitals often have well equipped laboratory services supporting their service provision and research.

\section{Study design and sampling technique}

This was a cross sectional survey of 20 out of 40 Federal, State and Private tertiary hospitals in Nigeria offering general acute and long-term cares and excluding the specialized hospitals. The list of all the Federal, State and Private tertiary hospitals was generated, and 3 hospitals were selected by balloting from each of the six geopolitical zones of the country. One additional hospital each was selected from two geopolitical zones with the highest number of tertiary hospitals. Only tertiary hospitals were included as they stood any chance of carrying out bacterial cultures, antimicrobial susceptibility and AMS given the resources available to them. The selected hospitals were then invited to participate in the survey

\section{Data collection instrument and analysis}

A semi-structured questionnaire adapted from the WHO template (22) was e-mailed by the principal investigator from the central study site to each selected centre through an identified focal person who completed the questionnaire for the participating centre and returned for central collation and analysis. The questionnaire had different sections which assessed the existence of AMS committee in the hospital, Accountability and Responsibility, AMS actions, Education and Training, Monitoring and Evaluation, Infection Prevention and Control (IPC) practice, facilities to support AMS, and challenges to AMS implementation.

Gaps and challenges facing the different hospitals in implementing AMS were identified. The responses were summarized and presented in frequency tables using Microsoft Excel 2016.

\section{Results:}

Of the 20 hospitals that participated in the survey, AMS committees were in existence in only $6(30 \%)$ hospitals. Two hospitals (10\%) had written evidence of leadership commitment while resource allocation by management and AMS policy document existed in only 1 (5\%) hospital (Table 1).

All the AMS committees in the 6 hospitals comprise multidisciplinary members with clearly defined leadership. Terms of reference were available in only 2 of the 6 (33.3\%) hospitals, while none has been having regular meetings of the committee or providing regular reports. Whereas 5 (25\%) of the 20 hospitals 
had IPC committees, only 1 (5\%) had an AMSIPC interface (Table 1).

Only 1 (5\%) hospital had any form of treatment guidelines in place. None had antibiotic approval or restriction policy or audit, and none gave regular feedback to prescribers. Hospital formulary was available in 4 (20\%) hospitals. One hospital has had training for prescribers and other stakeholders as at the time of the survey, but it was not sustained or regular. The only form of monitoring and evaluation in place was the periodic participation in the global point prevalence survey (GlobalPPS) of antimicrobial consumption and resistance hosted by the University of Antwerp,
Belgium, by a total of 7 (35\%) hospitals. Prescription sheets, drug charts and laboratory facilities for culture and antibiotic susceptibility were available in all the hospitals, while information technology (IT) facilities were available in $11(55 \%)$. None of the charts or prescription sheets were standardized for AMS activity. Antibiotic policy was present in $2(10 \%)$ hospitals (Table 1 ).

All hospitals identified some challenges to AMS implementation, which included lack of awareness, non-commitment of management, prescribers' challenge, and lack of human and financial resources (Table 2).

Table 1: Availability of AMS practices and identified gaps from hospitals in Nigeria

\begin{tabular}{|c|c|c|c|}
\hline \multirow{2}{*}{$\begin{array}{c}\text { AMS Elements } \\
\text { Antimicrobial } \\
\text { Stewardship Committee }\end{array}$} & Components of the AMS Elements & \multicolumn{2}{|c|}{$\begin{array}{c}\text { Present/Available } \\
n=20\end{array}$} \\
\hline & $\begin{array}{c}\text { Existence of AMS Committees } \\
\text { Written evidence of leadership commitment } \\
\text { Resource Allocation } \\
\text { AMS identified as priority } \\
\text { AMS policy document }\end{array}$ & $\begin{array}{l}\text { Yes (\%) } \\
6(30) \\
3(15) \\
1(5) \\
1(5) \\
1(5)\end{array}$ & $\begin{array}{l}\text { No (\%) } \\
14(70) \\
17(85) \\
19(95) \\
19(95) \\
19(95)\end{array}$ \\
\hline $\begin{array}{l}\text { Accountability and } \\
\text { Responsibility }\end{array}$ & $\begin{array}{c}\text { Multidisciplinary AMS Committee } \\
\text { AMS Terms of Reference } \\
\text { Regular Meetings }\end{array}$ & $\begin{array}{l}6(30) \\
2(10) \\
0\end{array}$ & $\begin{array}{c}14(70) \\
18(90) \\
20(100)\end{array}$ \\
\hline AMS Actions & $\begin{array}{c}\text { Treatment Guidelines } \\
\text { Antibiotic Approvals/Restrictions } \\
\text { Antibiotic Audit } \\
\text { Hospital Formulary }\end{array}$ & $\begin{array}{c}1(5) \\
0 \\
0 \\
4(20)\end{array}$ & $\begin{array}{c}19(95) \\
20(100) \\
20(100) \\
16(80)\end{array}$ \\
\hline Education and Training & Training for Prescribers and other AMS stakeholders & $1(5)$ & $19(95)$ \\
\hline $\begin{array}{l}\text { Monitoring and } \\
\text { Evaluation }\end{array}$ & $\begin{array}{c}\text { Indication, Dose, Duration, Route Monitoring } \\
\text { Surveillance }\end{array}$ & $\begin{array}{c}0 \\
7(35)\end{array}$ & $\begin{array}{l}20(100) \\
13(65)\end{array}$ \\
\hline Reporting and Feedback & $\begin{array}{c}\text { Regular reports to prescribers and others, and } \\
\text { Feedbacks }\end{array}$ & 0 & $20(100)$ \\
\hline AMS Support Facilities & $\begin{array}{l}\text { Clinical laboratories for culture and sensitivity } \\
\text { Prescription sheets } \\
\text { Drug charts } \\
\text { Standardized drug chart and prescription sheet } \\
\text { IT Facilities }\end{array}$ & $\begin{array}{l}20(100) \\
20(100) \\
20(100) \\
\quad 0 \\
11(55)\end{array}$ & $\begin{aligned} & 0 \\
& 0 \\
& 0 \\
20 & (100) \\
9 & (45)\end{aligned}$ \\
\hline IPC Activity & Antibiotic policy & $2(10)$ & $18(90)$ \\
\hline & $\begin{array}{c}\text { IPC Committee } \\
\text { AMS-IPC Interaction }\end{array}$ & $\begin{array}{l}5(25) \\
1(5)\end{array}$ & $\begin{array}{l}15(75) \\
19(95)\end{array}$ \\
\hline
\end{tabular}


Table 2: Identified challenges impeding AMS practice in Nigerian hospitals

\begin{tabular}{cc}
\hline Challenges & No of Hospitals (\%) \\
\hline Lack of Funding & $15(75)$ \\
Poor awareness of AMS usefulness by staff & $12(60)$ \\
Prescribers' opposition & $11(55)$ \\
Lack of IT Facilities & $9(45)$ \\
No ASP committee & $9(45)$ \\
Higher priorities & $8(40)$ \\
Lack of Staff & $8(40)$ \\
Administration not aware of programme & $7(35)$ \\
\hline ASP =Antimicrobial Stewardship Programme; IT= Information Technology & $6(30)$
\end{tabular}

ASP = Antimicrobial Stewardship Programme; IT= Information Technology

\section{Discussion:}

This cross-sectional survey was designed to identify factors hindering the practice of AMS in Nigeria tertiary hospitals. The results of our survey showed poor state of AMS practice among tertiary hospitals in Nigeria. Both the core and supplementary strategies were either non-existent or poorly practiced. The poor state of AMS practice is evidenced by the few AMS committees and near-total lack of leadership support and resource allocation. The health system has not identified AMS as a priority, hence the absence of policy and lack of resource allocation. This level of practice could explain the high level of antimicrobial use earlier reported in some Nigerian hospitals (23-26).

The few hospitals with AMS committees do not have any terms of reference and do not hold regular meetings. This could also partly explain the absence of leadership commitment or the reason for it. It will be challenging to operate a successful and sustainable AMS programme without leadership support and a functional AMS committee to drive the process. The near absence of AMS actions or interventions such as education and training, monitoring and evaluation, reporting and feedback might all be due to the absence of functional AMS committees, and leadership/administration support. Although the six hospitals with AMS committees had multidisciplinary members with clear leadership, this has not engendered the implementation of the supplementary strategies such as education and training, which calls to question the level of knowledge about AMS of the membership of these committees. An interesting aspect of the situation in these hospitals is the availability of adequate facilities for culture and sensitivity. Paradoxically, a previous study in Nigeria had identified poor use of the clinical microbiology laboratory by physicians (27). Some of the reasons advanced for the finding in this previous study included the belief by many physicians that "clinical diagnosis was sufficient", frustration at the "delay in getting results", physician having sufficient "knowledge of potent antibiotics", lack of access to clinical laboratory facilities, and non-availability of pathologists to assure the quality of laboratory tests. Under this scenario, a substantial number of prescriptions are bound to be or remain empiric and inappropriate, a situation that fuels antimicrobial resistance. In the absence of any significant AMS activity, there was nothing to monitor or evaluate. The participation in the global point prevalent survey was only a starting point for monitoring and evaluation activity.

The close relationship between AMS and IPC is well established $(22,28,29)$. Despite the availability of IPC committee in five hospitals, AMS-IPC interaction holds only in one hospital, suggesting lack of appreciation of the need for this. The absence of AMS committee in some of the hospitals could also have accounted for the absence of this valuable handshake. Alongside the huge AMS deficits highlighted here, there are also some notable challenges to implementation of AMS in the hospitals. These include but not limited to lack of funding, poor awareness of AMS usefulness by staff, prescribers' opposition, and lack of leadership support. Similar findings have been reported in a previous study of eleven hospitals in six continents $(30,31)$, where it was shown that, amongst others, the administrations in some of the study sites were not aware 
of the programme. It would therefore be difficult for the leadership to support a programme it was never aware of. This emphasizes the need for adequate and proper communication to ensure that all relevant interest groups and stakeholders are involved for a functional and sustainable AMS programme.

\section{Conclusion:}

In conclusion, AMS, a proven strategy in curbing AMR, is established in only few tertiary health facilities in Nigeria. This survey identified gaps and factors impeding the implementation of this strategy to include lack of education, training, and proper communication. If these gaps are addressed, it will aid the implementation and sustenance of AMS in these hospitals through appropriate measures that deal with issues of leadership support, lack of funding, prescribers' opposition, and low awareness of AMS usefulness by staff. The challenges of poor knowledge, implementation strategies, monitoring, reporting and feedback will also be largely addressed.

\section{Conflicts of interest:}

Authors declare no conflicts of interest

\section{Acknowledgements:}

The authors acknowledge the contributions of $A$. Kehinde and S. N. Ushie during the survey

\section{References:}

1. Letek, M. Alexander Fleming, The Discoverer of the Antibiotic Effects of Penicillin. Front Young Minds. 2020; 8: 159. doi: 10.3389/frym.2019.00159

2. Spellberg, B., and Taylor-Blake, B. On the exoneration of $\mathrm{Dr}$ William $\mathrm{H}$. Stewart: debunking an urban legend. Infect Dis Poverty. 2013; 2: 3. doi: 10.1186/2049-9957-2-3.

3. Alexander Fleming. Penicillin Nobel Lecture, December 11, 1945. Assessed 09 September 2020 https://www.nobelprize.org/uploads/2018/06/flem ing-lecture.pdf

4. Review on Antimicrobial Resistance. Antimicrobial Resistance: Tackling a Crisis for the Health and Wealth of Nations. 2014. The Review on Antimicrobial Resistance, Chaired by Jim O'Neill. Assessed 09 September 20202 from https://amrreview.org/sites/default/files/AMR\%20Review\%20 Paper\%20-\%20Tackling\%20a\%20crisis\%20for\% 20the\%20health\%20and\%20wealth\%20of\% 20nations_1.pdf

5. Abdullahi, N., and Iregbu, K. C. Methicillin-Resistant Staphylococcus aureus in a Central Nigeria Tertiary Hospital. Ann Trop Pathol. 2018; 9: 6-10

6. Azeez-Akande, O., Utsal, S. J., and Epoke, J. Distribution and antibiotic susceptibility pattern of methicillin-resistant Staphylococcus aureus isolates in a University Teaching hospital in Nigeria. Sahel Med J. 2008; 11 (4): 142-147. doi: $10.4314 / \mathrm{smj} 2 . v 11 \mathrm{i} 4.12989$

7. Taiwo, S. S., Onile, B. A., and Akanbi II, A. A. Methicillin-Resistant Staphylococcus aureus (MRSA) Isolates in Ilorin, Nigeria. Afr J Clin Exper Microbiol. 2004; 5(2): 189 - 197. doi:10.4314/ajcem.v5i2.7376

8. Kesah, C., Redjeb, S. B., Odugbemi, T. O, et al. Prevalence of methicillin-resistant Staphylococcus aureus in eight African hospitals and Malta. Clin Microbiol Infect. 2003; 9 (2): 153-156. doi: 10.1046/j.1469-0691.2003.00531.x.

9. Andersson, D. I., and Hughes, D. Persistence of Antibiotic Resistance in Bacterial populations. Microbiol Rev. 2011; 35 (5): 901-911. doi:org/10.1111/j.1574-6976.2011.00289.x

10. Munita, J. M., and Arias, C. A. Mechanism of Antibiotic Resistance. Microbiol Spectr 2016; 4 (2): doi/10.1128/microbiolspec.VMBF-0016-2015

11. Hecker, M. T., Aron, D. C., Patel, N. P., Lehmann, M. K., and Donskey, C. J. Unnecessary use of antimicrobials in hospitalized patients: current patterns of misuse with an emphasis on the antianaerobic spectrum of activity. Arch Intern Med. 2003; $28 ; \quad 163 \quad$ (8): $\quad 972-978$. doi:10.1001/archinte.163.8.972.

12. Tauman, A. V., Robicsek, A., Roberson, J., and Boyce, J. M. Health Care-Associated Infection Prevention and Control: Pharmacists' Role in Meeting National Patient Safety Goal 7. Hospital Pharmacy. 2007; 44 (5): 401-411

13. Chen, D. K., McGeer, A., de Azavedo, J. C., and Low, D. E. Decreased Susceptibility of Streptococcus pneumoniae to Fluoroquinolones in Canada. N Engl J Med. 1999; 341: 233-239. doi: 10.1056/NEJM199907223410403

14. Kim, B., Kim, Y., Hwang, H., et al. Trends and correlation between antibiotic usage and resistance pattern among hospitalized patients at university hospitals in Korea, 2004 to 2012: A nationwide multicenter study. Medicine. 2018; 97: 51(e13719) Olesen, S. W., Barnett, M. L., MacFadden, D. R., et al. The distribution of antibiotic use and its association with antibiotic resistance. elife. 2018; 7: e39435. doi:https://doi.org/10.7554/eLife.39435

16. World Health Organization. Antimicrobial Resistance: Global Burden. AMR Secretariat WHO, Geneva Switzerland. Assessed 10 September 2020 https://www.who.int/medicines/technical_briefing/ tbs/TBS2016 AMR GAP.pdf

17. World Health Organization. The world is running out of antibiotics, WHO report confirms. News Release, 2017; September 20. Geneva. Assessed 10 September 2020 https://www.who.int/newsroom/detail/20-09-2017-the-world-is-running-outof-antibiotics-who-report-confirms.

18. Center for Disease Control and Prevention. Management of Multidrug-Resistant Organisms in Healthcare Settings, 2006 Assessed 10 September 2020.https://www.cdc.gov/infectioncontrol/pdf/gui delines/mdro-guidelines.pdf.

19. Doron, S., and Davidson, L. E. Antimicrobial Stewardship. Mayo Clin Proc. 2011; 86 (11): 11131123. doi: $10.4065 / \mathrm{mcp} .2011 .0358$.

20. Center for Disease Control and Prevention. Core Elements of Hospital Antibiotic Stewardship Programs. Assessed 10 September 2020 from www/cdc.gov/getsmart/healthcare/inpatientstewardship.

21. Fadare, J. O., Ogunleye, O., Iliyasu, G., et al. Status of antimicrobial stewardship programmes in Nigerian tertiary healthcare facilities: Findings and implications. J Glob Antimicrob Resist. 2019; 17: 132-136. doi:10.1016/j.jgar.2018.11.025.

22. World Health Organization. Antimicrobial stewardship programmes in health-care facilities in low- and middle-income countries. A practical toolkit. Geneva: World Health Organization; 2019. 
Assessed 10 September 2020 from https://apps.who.int/iris/bitstream/handle/10665/ 329404/9789241515481-eng.pdf.

23. Nnadozie, N. N., Umeokonkwo, C. D., Maduba, C. C., et al. Antibiotic use among surgical inpatients at a tertiary health facility: a case for a standardized protocol for presumptive antimicrobial therapy in the developing world. Infection Prevention in $\begin{array}{llll}\text { Practice. } \quad 2020 ; & 2 & \text { (4): } 100078\end{array}$ https://doi.org/10.1016/j.infpip.2020.100078

24. Umeokonkwo, C. D., Madubueze, U. C., Onah, C. K., et al. Point Prevalence Survey of Antimicrobial Prescription in a Tertiary Hospital in South East Nigeria: A call for improved antibiotic stewardship. J Glob Antimicrob Resist. https://doi.org/10.1016/ j.jgar.2019.01.013

25. Oduyebo, O. O., Olayinka, A. T., Iregbu, K. C., et al. A point prevalence survey of antimicrobial prescribing in four Nigerian tertiary hospitals. Ann Trop Pathol. 2017; 8 (1): 42-46.

26. Abubakar, U. Antibiotic use among hospitalized patients in northern Nigeria: a multicenter pointprevalence survey. BMC Infect Dis. 2020; 20: 86 https://doi.org/10.1186/s12879-020-4815-4

27. Iregbu, K. C., Osuagwu, C. S., Umeokonkwo, C. D. et al. Underutilisation of the Clinical Microbiology laboratory by physicians in Nigeria. Afr J Clin Exper Microbiol. 2020; 21 (1): 53-59.

doi.org/10.4314/ajcem.v21i1.7

28. Scobie, A., Budd, E. L., Harris, R. J., Hopkins, S., and Shetty, N. Antimicrobial stewardship: an J Antimicrob Chemother. 2019; 74 (4): 11431152. doi.org/10.1093/jac/dky538.

29. Lonks, J. R. Infection Control and Antimicrobial Stewardship. R I Med J (2013). 2018;101 (5): 3537.

30. Howard, P., Pulcini, C., Hara, G. L., Harbath, S., Nathwani, D., and Gould, I. First global survey of antimicrobial stewardship (AMS). European Society for Clinical Microbiology and Infectious Diseases Study Group for Antimicrobial Policies (ESGAP) \& International Society for Chemotherapy Infection and Cancer Group on Antimicrobial Stewardship. European Conference on Clinical Microbiology and Infectious Diseases 2013, Berlin Presentation Number. 2448.

31. Manning, M. L., Septimus, E. J., Dodds Ashley, E. S., et al. Antimicrobial stewardship and infection prevention-leveraging the synergy: A position paper update. Am J Infect Contr. 2018; 46: 364368. Doi.org/10/1016/j-ajic.2018.01.001 